Revta brasil. Bot., São Paulo, V.24, n.3, p.333-347, set. 2001

\title{
Anatomia foliar das espécies de Pteridaceae do Parque Estadual do Rio Doce (PERD) - MG' ${ }^{1}$
}

\author{
DEUSÂNGELA GRAÇANO ${ }^{2}$, ARISTÉA ALVES AZEVEDO ${ }^{2,4}$ e JEFFERSON PRADO ${ }^{3}$
}

(recebido: 16 de fevereiro de 2000; aceito: 20 de junho de 2001)

\begin{abstract}
Leaf anatomy of Pteridaceae species from Rio Doce State Park (PERD) - MG). This study was carried out with the objective of selecting leaf anatomical characters that can help the taxonomy of Pteridaceae species growing in the PERD. During a preliminary survey, carried out in PERD, 57 species of ferns within 27 genera from 15 families were collected. The most representative family was Pteridaceae, with 17 species distributed in four genera (Adiantum, Hemionitis, Pityrogramma and Pteris). The leaves of these species showed glabrous, hairy or scaled petioles with unistratified epidermis and cortex composed by parenchyma and sclerenchyma. One meristele, in Pteris and Hemionitis, and two or three meristeles in Adiantum and Pityrogramma represent the petiole vascular system. In the distal region, these meristeles are classified in Adiantum as "Onoclea" and "Asterochlaena" types, in Hemionitis as "Grammitis" type, in Pityrogramma as "Onoclea" type, and in Pteris as "Loxsoma" and "Pteris podophylla" types. Leaf blade showed an uniestratified epidermis with idioblasts (sclereides). Idioblasts were parallel, oblique or restricted to veins in Adiantum and Pityrogramma, and reinforcing the leaf margins in Pteris. Idioblasts were absent only in Hemionitis. In some species, leaf blades were hairy or scaled. Anomocytic stomata sometimes associated to diacytic type were observed in the leaf abaxial surface in Adiantum, Hemionitis and Pityrogramma. In Pteris, stomata polocytic occur associated to copolocytic type. The mesophyll was homogeneous with "armed" cells in most Adiantum species or with lobed cells tending to isodiametric in the other genera. Hairs or scales, stomata type, presence and idioblasts distribution in the epidermis, type and disposition of petiole vascular tissue were the most relevant anatomical characters for the Pteridaceae identification in the PERD.
\end{abstract}

RESUMO - (Anatomia foliar das espécies de Pteridaceae do Parque Estadual do Rio Doce (PERD) - MG). O objetivo desse estudo foi selecionar caracteres que possam auxiliar na taxonomia das espécies de Pteridaceae ocorrentes no PERD. Durante levantamento preliminar realizado no PERD, foram coletadas 15 famílias, 27 gêneros e 57 espécies de Pteridophyta. A família que apresentou maior número de representantes foi Pteridaceae com 17 espécies, distribuídas em quatro gêneros (Adiantum, Hemionitis, Pityrogramma e Pteris). As folhas destas espécies apresentam pecíolo glabro, piloso ou escamoso cuja epiderme é uniestratificada, córtex constituído por esclerênquima e parênquima e o sistema vascular representado por um meristelo, em Pteris e Hemionitis, e dois ou três meristelos em Adiantum e Pityrogramma. Na região distal do pecíolo, esses meristelos são classificados como do tipo "Onoclea" e "Asterochlaena" em Adiantum, "Grammitis" em Hemionitis, "Onoclea" em Pityrogramma e "Loxsoma" e "Pteris podophylla" em Pteris. A lâmina foliar apresenta epiderme uniestratificada com idioblastos esclerenquimáticos paralelos, oblíquos ou restritos às nervuras, em Adiantum e Pityrogramma e reforçando as margens, em Pteris; os idioblastos estão ausentes em Hemionitis. Algumas espécies apresentam a lâmina foliar pilosa ou escamosa. Os estômatos ocorrem na face abaxial das pínulas sendo anomocíticos, às vezes associados a diacíticos, em Adiantum, Hemionitis e Pityrogramma e polocíticos, associados a copolocíticos, em Pteris. O mesofilo homogêneo é constituído por células braciformes, na maioria das espécies de Adiantum, ou por células lobadas, tendendo a isodiamétricas, nos demais gêneros. Os caracteres anatômicos mais relevantes para a identificação das Pteridaceae do PERD foram: presença de pêlos ou escamas; tipos de estômatos; presença e distribuição de idioblastos na epiderme e tipo e disposição do(s) feixe(s) vascular(es) no pecíolo.

Key words - Pteridaceae, foliar anatomy, State Park of Rio Doce (MG)

\section{Introdução}

As Pteridophyta constituem um grupo taxonômico pobremente entendido, pois a alta

1. Parte da dissertação de mestrado de D. Graçano.

2. Universidade Federal de Viçosa, Departamento de Biologia Vegetal, Av. P. H. Rolfs, s/n, 36571-000 Viçosa, MG, Brasil.

3. Instituto de Botânica, Seção de Briologia e Pteridologia, Caixa Postal 4005, 01061-970 São Paulo, SP, Brasil.

4. Autor para correspondência: aazevedo@mail.ufv.br porcentagem de hibridização, entre outros fatores, tem levado a interpretações errôneas de famílias, gêneros e até mesmo de espécies, dando origem à criação de grupos artificiais. Estudos anatômicos e morfológicos podem fornecer novos caracteres para a correta identificação das espécies, como enfatizado por Guantay \& Terán (1995).

A anatomia foliar de Pteridophyta e Angiospermae tem sido usada com grande sucesso na solução de problemas taxonômicos (Stace 1989). Algumas características têm se revelado promissoras como critérios adicionais à taxonomia, tais como: 
composição da epiderme e do mesofilo, presença e distribuição do esclerênquima (esclereídes ou fibras), cristais, vascularização do pecíolo e venação (Solereder 1908, Fryns - Claessens \& Van Cotthem 1973, Van Cotthem 1973, White 1974, Dickison 1975, Metcalfe \& Chalk 1979, 1983).

Bower (1923) foi o primeiro a propor a utilização dos caracteres anatômicos nos estudos taxonômicos das Pteridophyta. Alguns pesquisadores têm evidenciado a importância desses caracteres nos estudos sobre a evolução e as relações filogenéticas entre os grupos de Pteridophyta (Prado 1989). White (1974) destaca um claro direcionamento da pesquisa anatômica em três linhas principais: a organização do meristema apical, os padrões de vascularização dos órgãos e o estudo comparativo dos tipos de estômatos e de sua ontogenia.

Ogura (1972), em sua obra sobre a anatomia comparada dos órgãos vegetativos de Pteridophyta, realizou estudos detalhados de várias famílias, reunindo um grande número de dados relevantes até os dias atuais. Entretanto, um número elevado de espécies ainda não foi estudado anatomicamente.

No levantamento realizado no Parque Estadual do Rio Doce (PERD), a maior área de floresta contínua do estado de Minas Gerais, sob proteção legal, foram coletados 15 famílias, 27 gêneros e 57 espécies de Pteridophyta (Graçano et al. 1998). A vegetação do PERD, classificada por Veloso et al. (1991) como floresta estacional semidecidual submontana ou floresta subcaducifolia, é composta por um mosaico de florestas primárias e secundárias; estas últimas originadas por grandes queimadas ocorridas, principalmente, na década de 60 (SOCT 1981).

Dentre as famílias de Pteridophyta encontradas no PERD, a mais representativa foi Pteridaceae com 17 espécies distribuídas em quatro gêneros: Adiantum, Hemionitis, Pityrogramma e Pteris (Graçano et al. 1998). A família Pteridaceae é bastante diversificada, com cerca de 35 gêneros ( 22 deles americanos), e apresenta ampla distribuição geográfica. Embora alguns autores, como Copeland (1947) e Pichi-Sermolli (1958), tenham procurado apresentar uma classificação acurada para a família, somente Tryon \& Tryon (1982) propuseram um arranjo mais consistente para as Pteridaceae, baseando-se em diversos aspectos morfológicos, anatômicos, citológicos e palinológicos, bem como em informações relativas à distribuição geográfica de seus membros.
As Pteridaceae constituem um grupo muito interessante de plantas, principalmente, pela grande heterogeneidade de seus gêneros e espécies, aliado ao fato de ser uma família com grande representatividade e importância, em nível florístico, na região neotropical (Prado 1993).

Considerando-se o número reduzido de informações sobre a anatomia das Pteridaceae, realizou-se a caracterização anatômica das folhas das espécies encontradas no PERD, com o objetivo de selecionar caracteres que possam fornecer subsídios para a taxonomia da família.

\section{Material e métodos}

As espécies e variedade de Pteridaceae estudadas foram: Adiantum curvatum Kaulf., A. dolosum Kunze, A. glaucescens Klotzsch, A. latifolium Lam., A. lucidum (Cav.) Sw., A. obliquum Willd., A. papillosum Handro, A. pulverulentum L., A. serratodentatum Willd., A. subcordatum Sw., A. terminatum Kunze ex Miq., A. tetraphyllum Willd., Hemionitis tomentosa (Lam.) Raddi, Pityrogramma calomelanos (L.) Link var. calomelanos, Pteris denticulata Sw. var. denticulata, P. leptophylla Sw. e P. propinqua J. Agardh. Todo material testemunho do presente trabalho encontra-se depositado nos herbários do Instituto de Botânica (SP) e da Universidade Federal de Viçosa (VIC).

A coleta de material botânico foi realizada ao longo das estradas e trilhas demarcadas no Parque Estadual do Rio Doce (PERD): Vinhático, Campolina, Salão Dourado, Mombaça, Ilha do Clei, Porto Capim, Aníbal, Lagoa Carioca. O PERD fica localizado no estado de Minas Gerais, nos municípios de Timóteo, Marliéria e Dionísio e compreende cerca de 36.000 ha. Faz parte da bacia hidrográfica do Rio Doce e está situado entre os paralelos $19^{\circ} 48^{\prime} 18^{\prime \prime}$ - 19²9' $24^{\prime}$ " S e meridianos $42^{\circ} 38^{\prime} 30^{\prime \prime}-42^{\circ} 28^{\prime} 18^{\prime \prime} \mathrm{W}$ (IEF 1994).

Amostras de pecíolo e da lâmina foliar das espécies estudadas, incluindo de espécimes encontrados nas diferentes trilhas, foram coletadas e fixadas em FAA (formaldeído 37\%, ácido acético glacial e etanol 50\%; 1:1:18,v:v) para confecção de lâminas permanentes e temporárias.

Para confecção das lâminas permanentes, de material sem inclusão, as amostras foram secionadas em micrótomo manual de mesa Leitz. Cortes transversais e longitudinais, após clarificação em hipoclorito de sódio (10\%), foram lavados e corados com azul de astra e fucsina básica, segundo metodologia de Roeser (1972), modificada. O azul de astra (astra blue 6GLL-Sigma) foi preparado a 0,5\%, em ácido tartárico 2\% (Kropp 1972), e a fucsina a 0,1\%, em etanol $50 \%$. Após coloração, os cortes foram desidratados em série etílica progressiva e xilol e montados em bálsamo do Canadá sintético. Foram feitas seções transversais das regiões proximal, mediana e distal do pecíolo para observação do sistema vascular.

Amostras da lâmina foliar fixadas em FAA foram, também, processadas segundo as técnicas usuais para montagem de lâminas permanentes, com inclusão em parafina, utilizando-se desidratração em série etílica (Johansen 1940) e a coloração com azul de astra e fucsina básica, já citada. 
Para evidenciar a venação, os estômatos, os idioblastos e os tricomas, amostras das lâminas foliares foram coletadas e colocadas em álcool $50 \%$ para posterior diafanização, conforme técnica descrita por Johansen (1940), modificada. Foram utilizados hidróxido de sódio (10\%), por duas horas, e hipoclorito de sódio (10\%), até clareamento da amostra. As amostras das espécies de Adiantum foram diafanizadas utilizando-se apenas hipoclorito de sódio, por cerca de $24 \mathrm{~h}$, pois o hidróxido de sódio causava danos à estrutura.

A maceração do pecíolo foi feita pelo método de Jeffrey (Purvis et al. 1964) sendo o material corado com safranina e as lâminas montadas em gelatina-glicerinada (Johansen 1940).

Em todas as espécies, foram feitos testes microquímicos utilizando-se floroglucina acidificada e lugol (Berlyn \& Miksche 1976); vermelho de rutênio (Langeron 1949) e sulfato ferroso (Johansen 1940) para detectar, respectivamente, lignina, amido, celulose e compostos fenólicos.

Os estômatos foram classificados de acordo com Thurston (1969) e Ogura (1972) e os tipos de tricomas de acordo com Ogura (1972), Metcalfe \& Chalk (1979) e Fahn (1990). A identificação dos tipos de feixe vascular do pecíolo e da lâmina foliar, seguiu o esquema proposto por Ogura (1972).

O estudo anatômico das espécies foi realizado sob microscopia de luz e para a documentação fotográfica foi utilizado um fotomicroscópio DOCUVAL (Zeiss Jena).

\section{Resultados}

Gênero Adiantum L. (figuras 1-21; tabela 1).

As espécies de Adiantum apresentam o pecíolo revestido por uma epiderme uniestratificada, cujas células têm as paredes celulósicas impregnadas por compostos fenólicos. Na maioria das espécies, ocorrem escamas (figura 1) na epiderme. Em $A$. papillosum foram observados pêlos unicelulares simples, com parede espessa e ápice rombudo (figura 2) e em A. terminatum pêlos unisseriados pluricelulares. Em A. curvatum, A. glaucescens e A. subcordatum o pecíolo é glabro.

O córtex é constituído por esclerênquima (fibras), de localização subepidérmica, e por parênquima (figura 3). As fibras são estreitas, alongadas, com extremidades afiladas e suas paredes celulósicas espessadas podem se apresentar impregnadas por compostos fenólicos, o que confere ao tecido uma coloração escura. $\mathrm{O}$ parênquima apresenta células levemente alongadas e espaços intercelulares conspícuos. Nas células próximas à endoderme pode-

Tabela 1. Caracteres anatômicos foliares de espécies de Pteridaceae coletadas, em diferentes ambientes, no Parque Estadual do Rio Doce, MG.

\begin{tabular}{|c|c|c|c|c|c|c|c|c|c|}
\hline \multirow[b]{3}{*}{ Espécies } & \multirow[b]{3}{*}{ Ambiente } & \multicolumn{5}{|c|}{ Lâmina foliar } & \multicolumn{3}{|c|}{ Pecíolo } \\
\hline & & \multicolumn{4}{|c|}{ Epiderme } & \multirow{2}{*}{$\begin{array}{c}\text { Mesofilo } \\
\text { Forma } \\
\text { da } \\
\text { célula }\end{array}$} & \multirow{2}{*}{$\begin{array}{c}\text { Epiderme } \\
\text { Escamosa, } \\
\text { pilosa } \\
\text { ou glabra }\end{array}$} & \multicolumn{2}{|c|}{$\mathrm{N}^{\circ}$ de feixes } \\
\hline & & $\begin{array}{c}\text { Escamosa, } \\
\text { pilosa } \\
\text { ou glabra }\end{array}$ & $\begin{array}{l}\text { Tipo(s) de } \\
\text { estômato(s) }\end{array}$ & $\begin{array}{l}\text { Paredes } \\
\text { anticlinais }\end{array}$ & $\begin{array}{c}\text { Idioblastos: } \\
\text { posição em } \\
\text { relação às } \\
\text { nervuras }\end{array}$ & & & $\begin{array}{l}\mathrm{Na} \\
\text { região } \\
\text { basal }\end{array}$ & $\begin{array}{l}\mathrm{Na} \\
\text { região } \\
\text { distal }\end{array}$ \\
\hline Adiantum curvatum & sombreado & glabra & anomocítico & sinuosas & restritos & braciforme & glabra & 2 & 1 \\
\hline Adiantum dolosum & sombreado & escamosa & anomocítico & sinuosas & paralelos & braciforme & escamosa & 2 & 1 \\
\hline Adiantum glaucescens & sombreado & glabra & anomocítico & sinuosas & oblíquos & braciforme & glabra & 2 & 1 \\
\hline Adiantum latifolium & sombreado & glabra & anomocítico & sinuosas & oblíquos & lobada & escamosa & 2 & 1 \\
\hline Adiantum lucidum & sombreado & escamosa & anomocítico & sinuosas & paralelos & braciforme & escamosa & 2 & 1 \\
\hline Adiantum obliquum & sombreado & glabra & anomocítico & sinuosas & paralelos & braciforme & escamosa & 2 & 1 \\
\hline Adiantum papillosum & sombreado & glabra & $\begin{array}{l}\text { anomocítico } \\
\text { e diacítico }\end{array}$ & sinuosas & restritos & braciforme & pilosa & 3 & 2 \\
\hline Adiantum pulverulentum & sombreado & escamosa & anomocítico & sinuosas & paralelos & lobada & escamosa & 2 & 1 \\
\hline Adiantum subcordatum & sombreado & glabra & $\begin{array}{l}\text { anomocítico } \\
\text { e diacítico }\end{array}$ & sinuosas & restritos & braciforme & glabra & 3 & 2 \\
\hline Adiantum terminatum & sombreado & $\begin{array}{c}\text { pilosa } \\
\text { (pêlos tectores) }\end{array}$ & anomocítico & sinuosas & oblíquos & lobada & pilosa & 2 & 1 \\
\hline Adiantum tetraphyllum & sombreado & escamosa & anomocítico & sinuosas & paralelos & braciforme & escamosa & 2 & 1 \\
\hline Hemionitis tomentosa & sombreado & $\begin{array}{c}\text { pilosa } \\
\text { (pêlos tectores } \\
\text { e glandulares) }\end{array}$ & anomocítico & sinuosas & ausentes & lobada & $\begin{array}{l}\text { escamosa } \\
\text { e pilosa }\end{array}$ & 1 & 1 \\
\hline $\begin{array}{l}\text { Pityrogramma calomelanos } \\
\text { var. calomelanos }\end{array}$ & pleno sol & $\begin{array}{l}\text { pilosa (pêlos } \\
\text { glandulares) }\end{array}$ & $\begin{array}{l}\text { anomocítico } \\
\text { e diacítico }\end{array}$ & $\begin{array}{l}\text { levemente } \\
\text { onduladas }\end{array}$ & restritos & lobada & glabra & 4 & 2 \\
\hline $\begin{array}{l}\text { Pteris denticulata } \\
\text { var. denticulata }\end{array}$ & sombreado & $\begin{array}{c}\text { pilosa } \\
\text { (pêlos tectores) }\end{array}$ & $\begin{array}{l}\text { polocítico e } \\
\text { copolocítico }\end{array}$ & recortadas & marginais & lobada & glabra & 1 & 1 \\
\hline Pteris leptophylla & sombreado & $\begin{array}{c}\text { pilosa } \\
\text { (pêlos tectores) }\end{array}$ & $\begin{array}{l}\text { polocítico e } \\
\text { copolocítico }\end{array}$ & recortadas & marginais & lobada & glabra & 1 & 1 \\
\hline Pteris propinqua & sombreado & $\begin{array}{c}\text { pilosa } \\
\text { (pêlos tectores) }\end{array}$ & $\begin{array}{l}\text { polocítico e } \\
\text { copolocítico }\end{array}$ & recortadas & ausentes & lobada & glabra & 1 & 1 \\
\hline
\end{tabular}



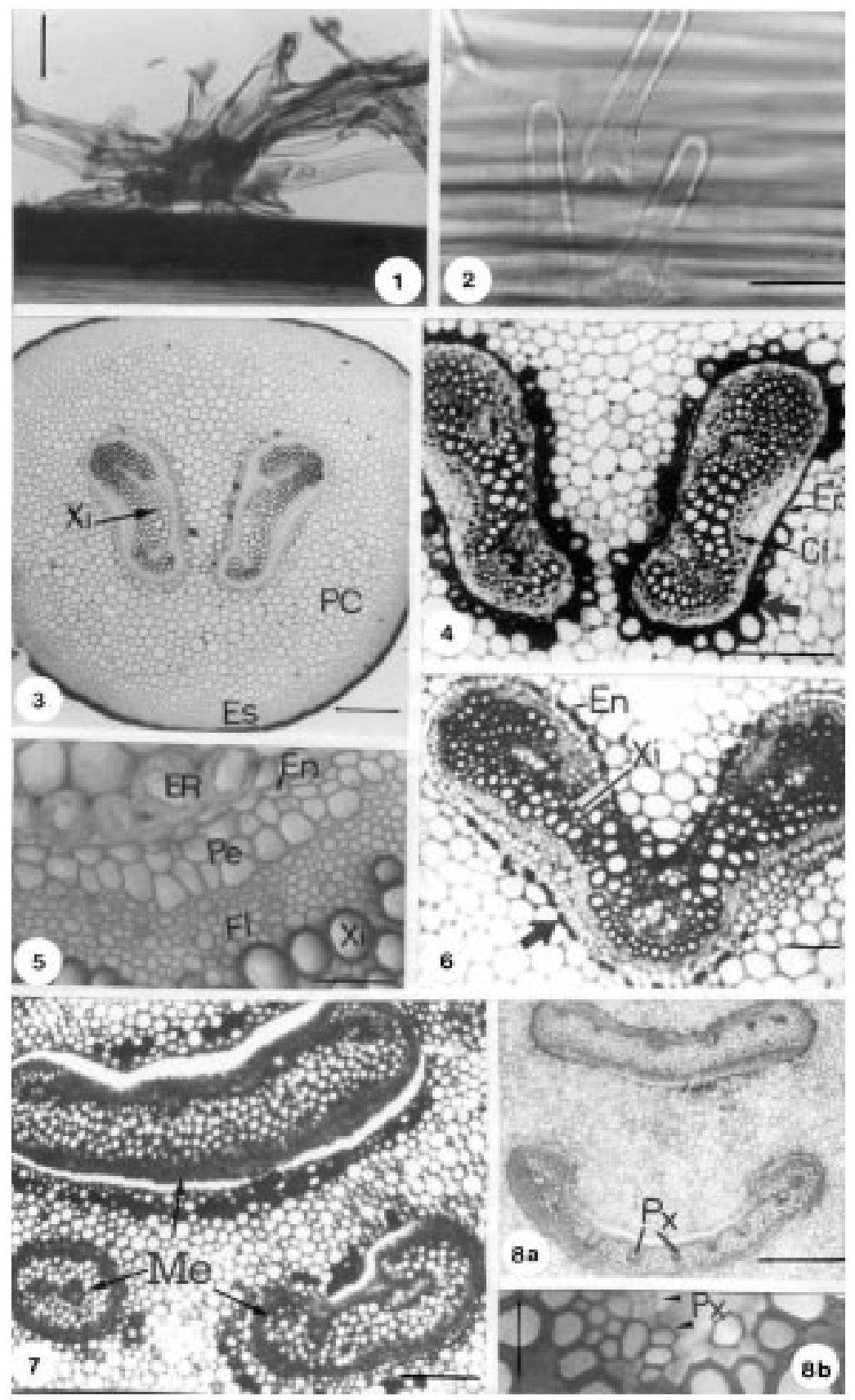

6
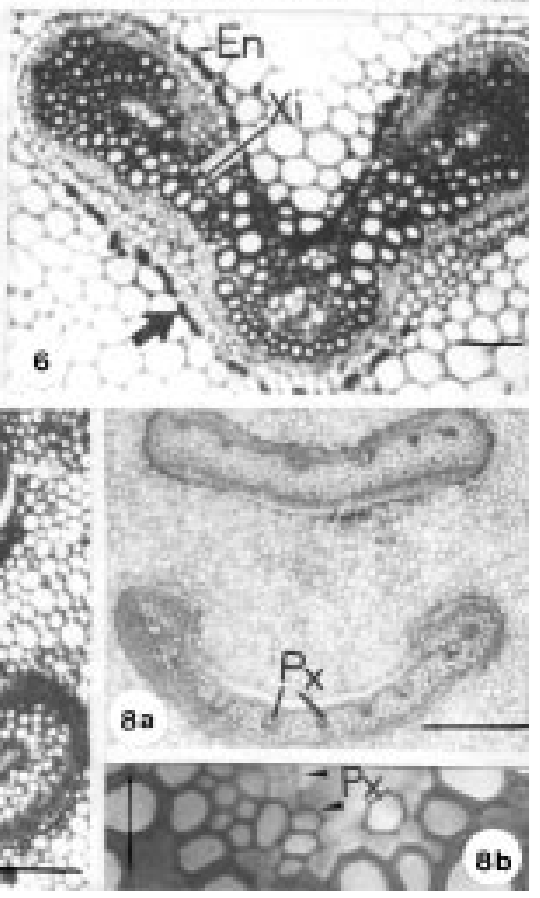

Figuras 1-8. Estrutura do pecíolo de espécies de Adiantum. 1. Corte longitudinal mostrando escama na epiderme de A. pulverulentum $($ barra $=10 \mu \mathrm{m})$. 2. Epiderme de A. papillosum, em corte paradérmico, com pêlos simples de ápice rombudo (barra $=50 \mu \mathrm{m})$. 3-8. Cortes transversais. 3. Região basal: parênquima cortical $(\mathrm{PC})$, esclerênquima subepidérmico (Es) e presença de dois meristelos com xilema (Xi) em forma de "cavalo marinho", em A. pulverulentum (barra $=20 \mu \mathrm{m}) .4$. Endoderme (En), células parenquimáticas do córtex (seta) e do floema (cf) com conteúdo escuro, em A. dolosum (barra = 25 $\mu \mathrm{m})$. 5. Detalhe do meristelo: células parenquimáticas, próximas à endoderme (En), com espessamento de aspecto radiado (ER); periciclo $(\mathrm{Pe})$ com 2-3 camadas de células; floema $(\mathrm{Fl})$ e xilema (Xi), em A. pulverulentum (barra $=10 \mu \mathrm{m}$ ). 6 . Região distal: xilema $(\mathrm{Xi})$ formando uma estrutura em "V", presença de endoderme com conteúdo escuro (seta), em A. glaucescens $($ barra $=25 \mu \mathrm{m}) .7$ e 8 . A. subcordatum. 7. Região basal do pecíolo, com três meristelos $(\mathrm{Me})($ barra $=500 \mu \mathrm{m})$. $8 \mathrm{a}$. Região distal do pecíolo com dois meristelos em forma de "arco atenuado" e vários pólos de protoxilema $(\mathrm{Px})(\mathrm{barra}=50 \mathrm{~mm})$. $8 \mathrm{~b}$. Detalhe de um pólo de protoxilema $(\mathrm{Px})$ (barra $=50 \mu \mathrm{m})$. 
se observar, algumas vezes, além do conteúdo escuro (figura 4), paredes com espessamento de aspecto radiado (figura 5) e pontoações simples, como em Adiantum dolosum, A. latifolium, A. pulverulentum e A. papillosum. A endoderme (figuras 4, 5) envolve cada meristelo e apresenta células com estrias de Caspary e, muitas vezes, com conteúdo escuro (figuras 4,6), exceto em Adiantum curvatum e A. subcordatum.

$\mathrm{Na}$ região basal do pecíolo, ocorrem dois meristelos (figuras 3,4) que aparecem unidos na região distal, ficando o sistema vascular envolvido por uma única endoderme (figura 6). Cada meristelo apresenta: periciclo formado por uma ou duas camadas de células (figura 5); floema situado em torno do xilema e, muitas vezes, com células parenquimáticas de conteúdo escuro (figura 4); xilema em forma de "cavalo-marinho" na região basal do pecíolo, tipo "Onoclea" (figuras 3, 4) e em forma de "U" ou "V", com as margens em ganchos recurvados, tipo "Loxsoma", na região distal (figura 6); presença de dois pólos de protoxilema, com traqueídes aneladas e espiraladas; e de metaxilema com traqueídes escalariformes.

Adiantum papillosum e A. subcordatum constituem exceções, dentre as espécies estudadas, pois, na região basal do pecíolo, o sistema vascular está representado por três meristelos (figura 7). Os dois meristelos menores, voltados para a face abaxial, unem-se e, em conseqüência, na região distal do pecíolo são observados dois meristelos (figura 8). Cada meristelo apresenta xilema em forma de "arco atenuado" tipo "Asterochlaena", com 6-9 pólos de protoxilema (figuras $8 \mathrm{a}, 8 \mathrm{~b}$ ).

A lâmina foliar apresenta a epiderme uniestratificada com as células da epiderme adaxial alongadas em vista frontal, em geral estreitas (figura 9), enquanto, as da epiderme abaxial tem forma irregular e paredes anticlinais mais sinuosas (figura 10). Os estômatos estão presentes apenas na face abaxial das pínulas, predominando o tipo anomocítico (figura 10). Nas células-guarda pode ser evidenciado espessamento radiado de parede, partindo da região adjacente ao ostíolo, como visto em Adiantum curvatum, A. glaucescens, A. latifolium, A. pulverulentum e A. serratodentatum, ou espessamento na região de união das células-guarda como em A. dolosum. Em Adiantum papillosum e A. subcordatum, ao contrário do que ocorre nas demais espécies, as células epidérmicas, de ambas as faces das pínulas, têm forma irregular e paredes anticlinais profundamente sinuosas; na face abaxial (figura 10) foram observados estômatos diacíticos, além de estômatos anomocíticos.

Todas as espécies apresentam, na epiderme de ambas as faces das pínulas, idioblastos esclerenquimáticos que são células longas, estreitas, de paredes celulósicas espessas, retilíneas ou sinuosas (figuras 9-11). Em Adiantum curvatum, $A$. papillosum e A. subcordatum os idioblastos têm localização restrita às nervuras (figura 10); nas demais espécies, os idioblastos podem ser observados paralelos às nervuras (figura 9), como em Adiantum dolosum, A. lucidum, A. obliquum, A. pulverulentum, A. serratodentatum e A. tetraphyllum, ou oblíquos a estas (figura 11), como em A. glaucescens, A. latifolium e A. terminatum. Idioblastos curtos e perpendiculares às nervuras foram observadas no indúsio (figura 12) da maioria das espécies, com exceção de Adiantum curvatum, A. glaucescens, A. papillosum e A. subcordatum.

A lâmina foliar das espécies estudadas pode ser glabra, como em Adiantum curvatum, A. glaucescens, A. latifolium, A. obliquum, A. papillosum e A. subcordatum, ou pode apresentar escamas ou pêlos. Na epiderme abaxial de Adiantum dolosum, A. lucidum, A. pulverulentum, A. serratodentatum e $A$. tetraphyllum ocorrem escamas esparsas (figura 13), enquanto em A. terminatum foram observados, na epiderme abaxial, pêlos articulados, unisseriados e pluricelulares (figura 14), idênticos aos do pecíolo. No indúsio de Adiantum serratodentatum foram observados pêlos pluricelulares unisseriados (figura 15).

As células da epiderme adaxial são, em geral, clorofiladas e, na maioria das espécies, apresentam a parede periclinal interna com projeções de aspecto ungulado (figuras 16, 17). Em Adiantum serratodentatum a epiderme é aclorofilada sem projeções na parede periclinal interna (figura 18).

A espessura do mesofilo varia de uma camada de células (figura 16), como em A. curvatum, a várias camadas (em geral de 4-8), como nas demais espécies (figuras 17-20).

Em nenhuma das espécies foi observada a diferenciação do mesofilo em parênquima paliçádico e lacunoso; entretanto, o parênquima clorofiliano tende a ser mais compacto nas camadas próximas à epiderme adaxial (figuras 17-20). O mesofilo apresenta as células de paredes delgadas com a forma destas células variando de lobada (figura 19), como em 

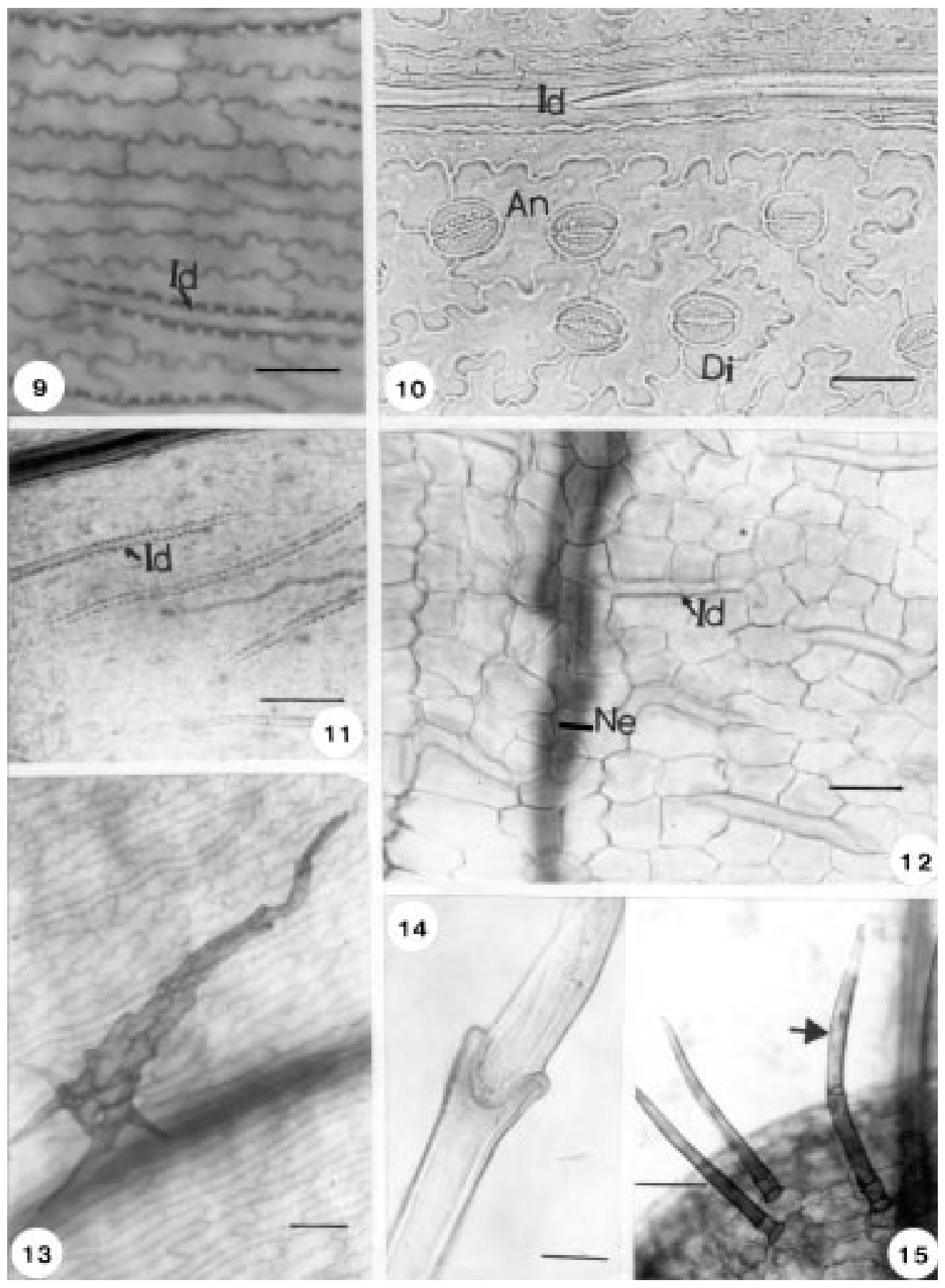

Figuras 9-15. Epiderme foliar de espécies de Adiantum (material diafanizado). 9. Epiderme adaxial de A. dolosum com células estreitas e alongadas e idioblastos (Id) de paredes sinuosas paralelos às nervuras (barra $=15 \mu \mathrm{m}$ ). 10. Epiderme abaxial de $A$. papillosum com células de paredes anticlinais sinuosas; estômatos diacíticos (Di) e anomocíticos (An); idioblastos (Id) de paredes retilíneas, restritos às nervuras (barra $=10 \mu \mathrm{m})$. 11. Idioblastos $(\mathrm{Id})$ de paredes sinuosas, oblíquos às nervuras, em $A$. glaucescens $($ barra $=25 \mu \mathrm{m})$. 12. Indúsio de A. pulverulentum com idioblastos $(\mathrm{Id})$ perpendiculares às nervuras $(\mathrm{Ne})(\mathrm{barra}=$ $15 \mu \mathrm{m})$. 13. Escama na epiderme abaxial de A. dolosum (barra $=15 \mu \mathrm{m})$. 14. Detalhe do pêlo tector simples, na epiderme abaxial de $A$. terminatum, mostrando a articulação entre duas células (barra $=5 \mu \mathrm{m}$ ). 15. Pêlos tectores (seta) no indúsio de $A$. serratodentatum (barra $=20 \mu \mathrm{m})$. 

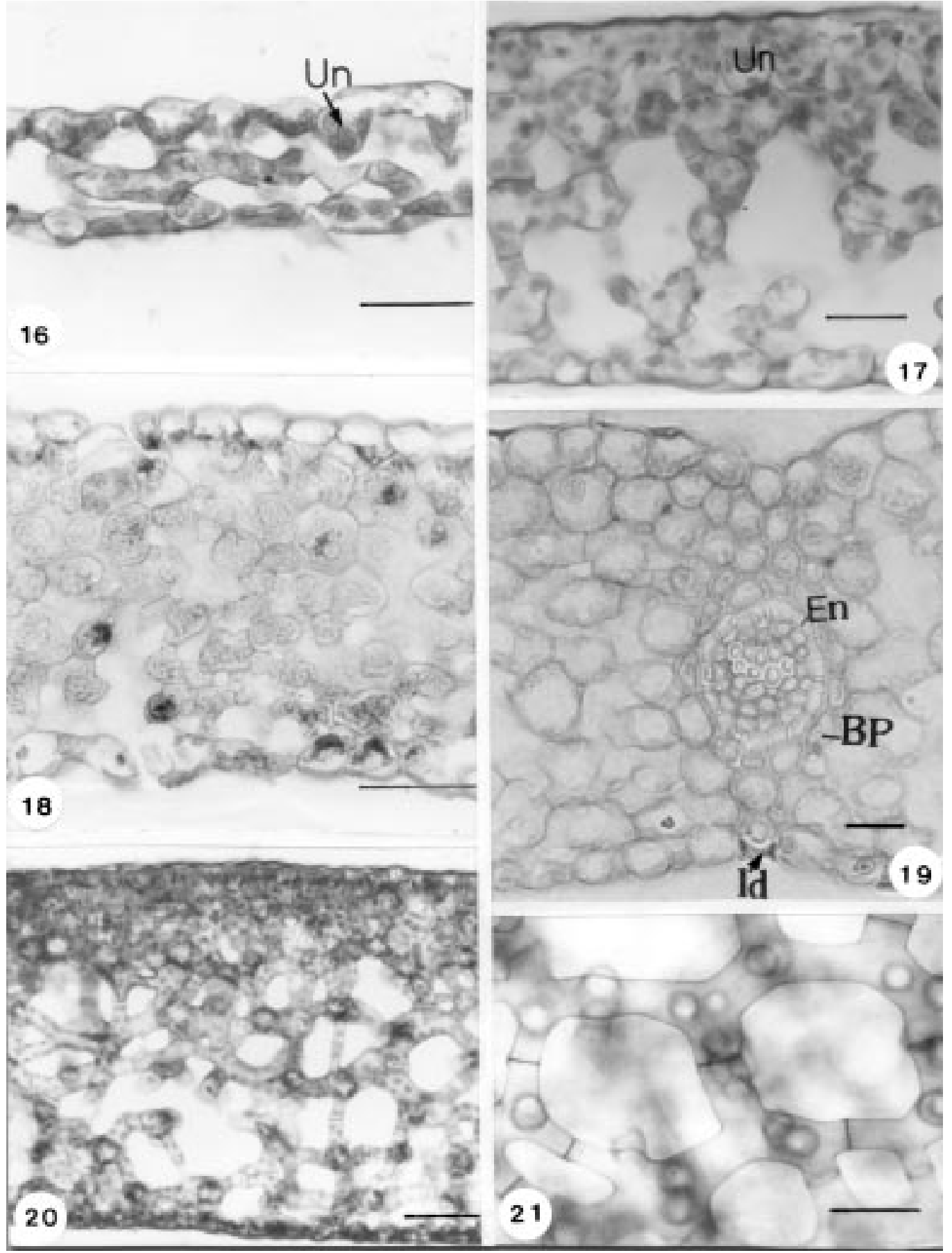

Figuras 16-21. Estrutura geral da lâmina foliar de espécies de Adiantum. 16-20. Cortes transversais. 16. Mesofilo com uma camada de células e epiderme adaxial com células clorofiladas de aspecto ungulado (Un), em A. curvatum (barra =50 $\mu \mathrm{m}$ ). 17. Mesofilo com células braciformes e epiderme adaxial com células clorofiladas de aspecto ungulado (Un), em A. glaucescens (barra $=10 \mu \mathrm{m}) .18$. Mesofilo homogêneo e epiderme adaxial aclorofilada, sem projeções na face interna, em A. serratodentatum (barra = 50 $\mu \mathrm{m}$ ). 19. Mesofilo espesso, com células lobadas; idioblastos (Id) na epiderme abaxial; feixe vascular envolvido pela endoderme (En) e por bainha parenquimática (BP), em A. pulverulentum (barra $=5 \mu \mathrm{m})$. 20. Mesofilo com células braciformes cujo arranjo é mais compacto próximo à epiderme adaxial, em A. dolosum (barra $=95 \mu \mathrm{m})$. 21. Detalhe do parênquima braciforme na lâmina foliar diafanizada de A. dolosum (barra $=50 \mu \mathrm{m})$. 
Adiantum latifolium, A. pulverulentum, A. serratodentatum e A. terminatum, até células braciformes (figuras 20,21), como nas demais espécies.

Na lâmina foliar, foram observados feixes colaterais ou anficrivais sendo os feixes de maior porte anficrivais e os de menor portes colaterais. Cada feixe está envolvido pelo periciclo, com uma camada de células, e pela endoderme (figura 19), cujas células apresentam estrias de Caspary e contêm, muitas vezes, compostos fenólicos. Os feixes vasculares de menor porte situam-se na região mediana do mesofilo e estão envolvidos pelo parênquima clorofiliano, podendo apresentar extensão de bainha parenquimática.

\section{Gênero Hemionitis (figuras 22-30; tabela 1).}

No pecíolo de Hemionitis tomentosa, única espécie do gênero registrada no Parque, a epiderme é uniestratificada e apresenta escamas na região basal e pêlos tectores simples ao longo de todo o pecíolo. Os pêlos apresentam a base estreita (figura 22) e são constituídos por uma ou duas células de paredes espessadas. As células da epiderme e as fibras subepidérmicas têm paredes impregnadas por compostos fenólicos. Na região mais interna do córtex, observamos um parênquima de paredes delgadas (figura 23).

O único meristelo presente, em toda a extensão do pecíolo (figuras 23, 24), está envolvido pelo periciclo, com duas ou mais camadas de células, e pela endoderme. O xilema apresenta-se dividido em três grupos de células na região basal do pecíolo, sendo dois grupos maiores de metaxilema, com formato arqueado, e um menor de protoxilema, arredondado e localizado abaxialmente (figura 24). Na região distal do pecíolo, os dois grupos maiores de xilema unemse formando uma estrutura semelhante a um "V", com o vértice truncado, do tipo "Grammitis" (figura 23).

A lâmina foliar de $H$. tomentosa apresenta a epiderme uniestratificada, clorofilada, constituída, nas duas faces da lâmina, por células de paredes sinuosas (figuras 25, 26). Na face abaxial das pínulas ocorrem estômatos anomocíticos (figura 26), estando as células-guarda mais elevadas em relação às demais células epidérmicas.

Na face abaxial da lâmina foliar, que é mais pilosa que a face adaxial, foram observados três tipos de pêlos: tectores pluricelulares (2-7 células), tectores bicelulares e glandulares. O pêlo tector pluricelular é unisseriado, articulado, com intumescimento na região de união das células (figura 27); o pêlo tector bicelular é curto e acicular (figura 28), com espessamento radiado na parede da célula basal e o pêlo glandular apresenta três células sendo a distal dilatada (figura 29). Na face adaxial, os pêlos bicelulares estão concentrados na região das nervuras, os pluricelulares ocorrem por toda a lâmina foliar e os glandulares estão ausentes.

Em corte transversal, pode-se observar que as células da epiderme adaxial apresentam as paredes periclinais internas com projeções unguladas (figura 29). O mesofilo apresenta-se homogêneo com células de organização frouxa, não se observando diferenciação de parênquima paliçádico e lacunoso, mas verifica-se que as células do parênquima clorofiliano têm um arranjo mais compacto próximo à epiderme adaxial (figura 29).

Na região da nervura mediana (figura 30), observa-se um feixe vascular anficrival, delimitado pelo periciclo e circundado pela endoderme, cujas células apresentam estrias de Caspary. Os feixes colaterais, de menor porte, estão situados na região mediana do mesofilo e em torno da endoderme ocorre uma bainha parenquimática.

\section{Gênero Pityrogramma (figuras 31-37; tabela 1)}

Pityrogramma calomelanos (L.) Link. var. calomelanos, a única espécie do gênero encontrado no Parque, apresenta pecíolo glabro com epiderme uniestratificada cujas células têm paredes celulósicas impregnadas por compostos fenólicos (figura 31).

O córtex é constituído por um tecido subepidérmico esclerenquimático e por um parênquima (figura 31). As fibras esclerenquimáticas são estreitas, alongadas, de extremidades afiladas e paredes, muitas vezes, impregnadas por compostos fenólicos. O parênquima apresenta células volumosas de paredes celulósicas delgadas.

$\mathrm{Na}$ região basal do pecíolo, o sistema vascular está constituído por quatro meristelos, sendo dois menores voltados para a face adaxial e dois maiores voltados para a face abaxial (figura 32); na região mediana, ocorre união de cada meristelo menor com o maior constituindo dois meristelos que permanecem separados até a região distal do pecíolo (figura 33). Cada meristelo está envolvido pela endoderme e apresenta: periciclo com uma ou mais camadas de células; floema em torno do xilema; xilema em forma de "cavalo-marinho" (figura 33), do tipo "Onoclea", 

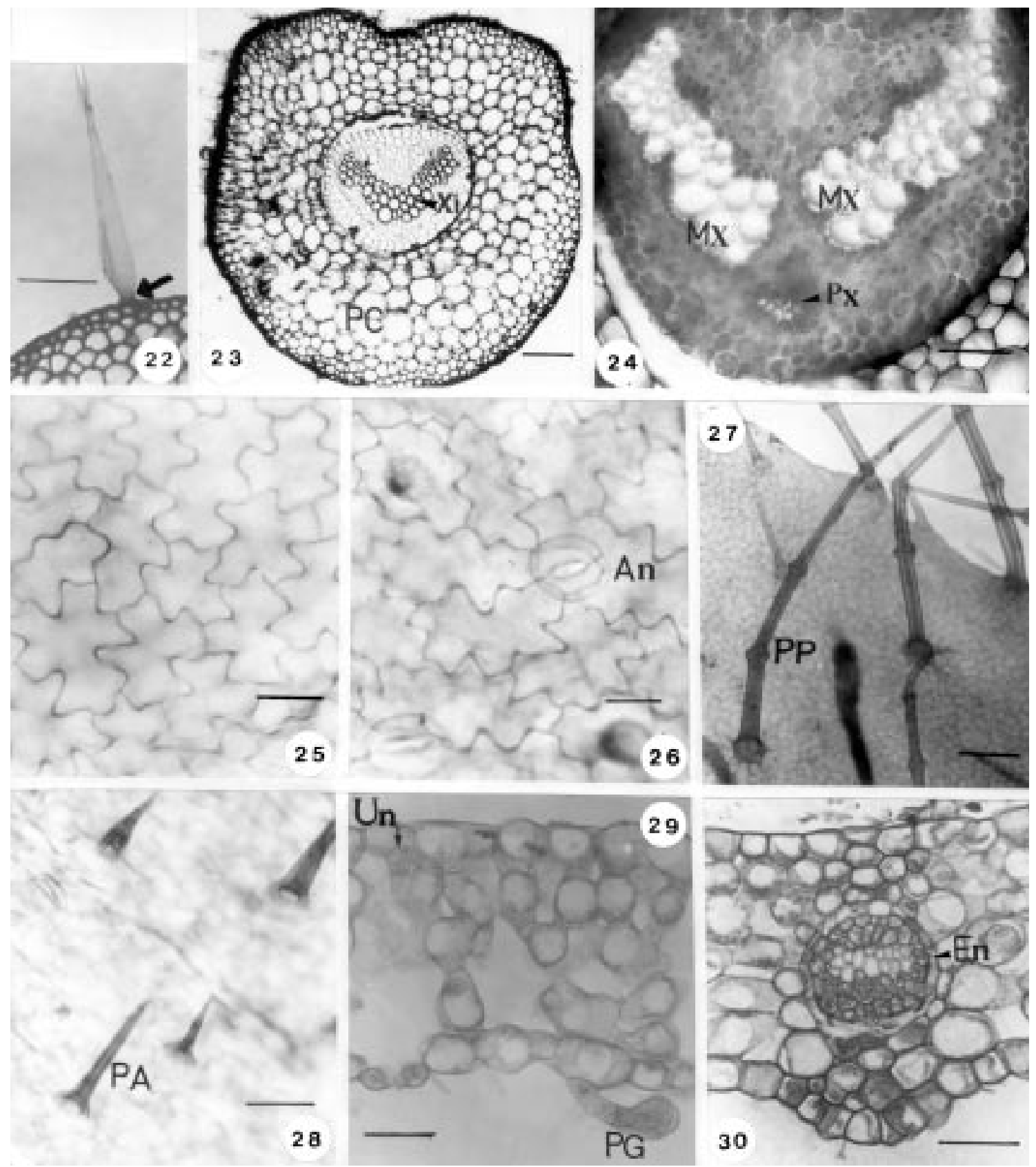

Figuras 22-30. Estrutura foliar de Hemionitis tomentosa. 22-24. Cortes transversais do pecíolo. 22. Epiderme com pêlos simples de base estreitada (seta) (barra $=25 \mu \mathrm{m}$ ). 23. Região distal evidenciando um único feixe com xilema (Xi) em forma de "V" (barra $=15 \mu \mathrm{m}$ ) e parênquima cortical (PC). 24. Detalhe do meristelo, na região basal, com dois grupos de metaxilema $(\mathrm{Mx})$ e um grupo abaxial de protoxilema $(\mathrm{Px})($ barra $=10 \mu \mathrm{m})$. 25-28. Lâmina foliar diafanizada. 25. Epiderme adaxial com células de paredes sinuosas (barra $=5 \mu \mathrm{m})$. 26. Epiderme abaxial com estômatos anomocíticos $($ An $)($ barra $=5 \mu \mathrm{m})$. 27. Face abaxial com pêlos tectores simples, articulados e pluricelulares (PP) (barra $=15 \mu \mathrm{m}$ ). 28. Pêlos tectores bicelulares, aciculares (PA) $($ barra $=15 \mu \mathrm{m}) .29$ e 30. Cortes transversais da lâmina foliar. 29. Células da epiderme adaxial com aspecto ungulado (Un); pêlo glandular $(\mathrm{PG})$ na epiderme abaxial; mesofilo indiferenciado (barra $=50 \mu \mathrm{m}$ ). 30 . Nervura mediana com feixe anficrival envolvido pela endoderme $($ En) $($ barra $=10 \mu \mathrm{m})$. 


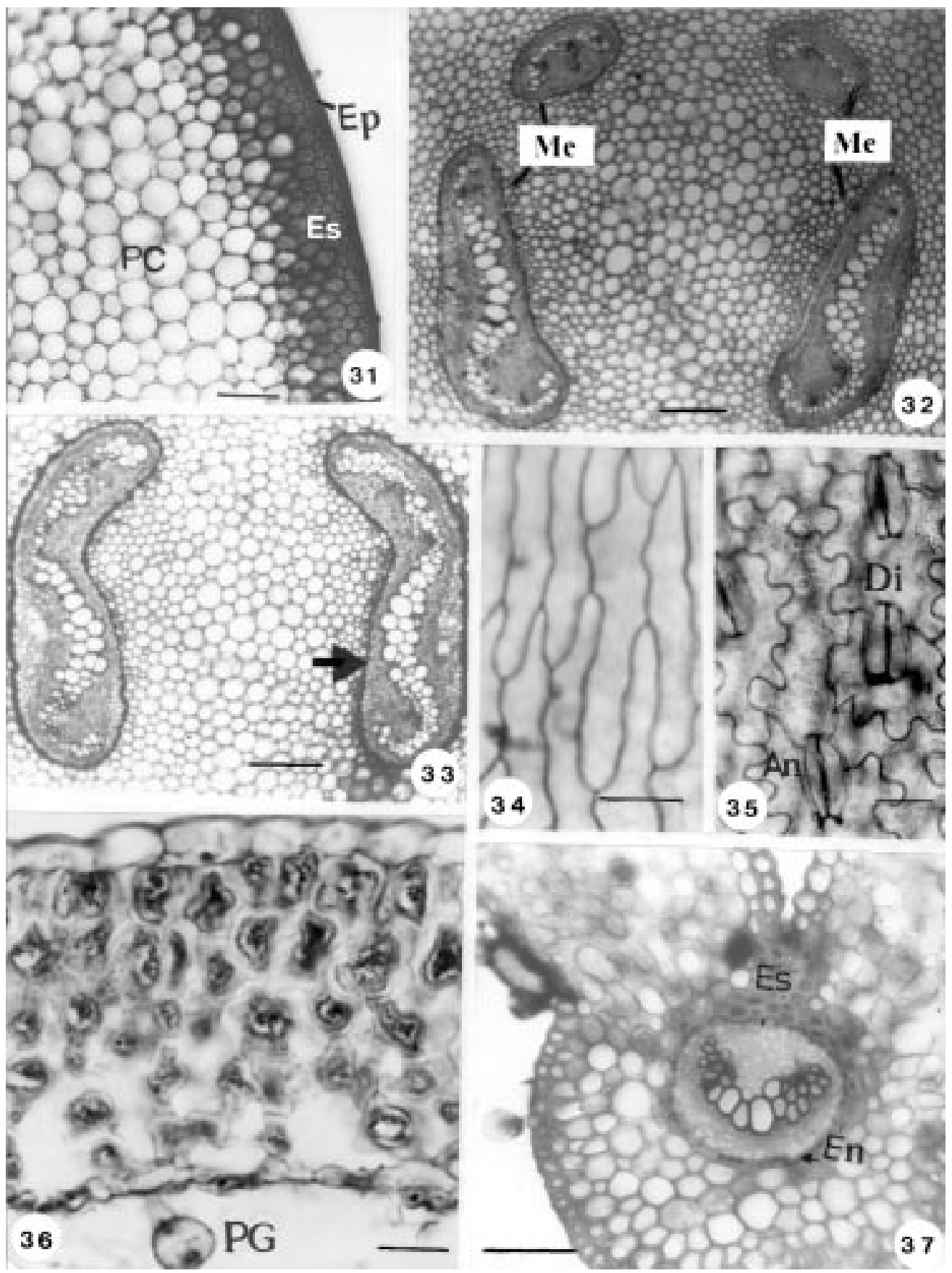

Figuras 31-37. Estrutura foliar de Pityrogramma calomelanos var. calomelanos. 31-33. Cortes transversais do pecíolo. 31. Epiderme uniestratificada (Ep) impregnada por compostos fenólicos, esclerênquima subepidérmico (Es) e parênquima cortical (PC) $($ barra $=125 \mu \mathrm{m})$. 32. Região basal com quatro meristelos $(\mathrm{Me})($ barra $=25 \mu \mathrm{m})$. 33. Região distal com dois meristelos e células da endoderme com conteúdo escuro (seta) (barra $=50 \mu \mathrm{m}$ ). 34 e 35. Lâmina foliar diafanizada. 34. Epiderme adaxial com células de paredes anticlinais levemente onduladas (barra $=15 \mu \mathrm{m})$. 35. Epiderme abaxial com células de paredes anticlinais sinuosas, estômatos diacíticos (Di) e anomocíticos $(\mathrm{An})$ (barra $=10 \mu \mathrm{m}$ ). 36 e 37 . Cortes transversais da lâmina foliar. 36. Mesofilo tendendo a dorsiventral; pêlo glandular $(\mathrm{PG})$ na epiderme abaxial (barra $=10 \mu \mathrm{m}$ ). 37. Região da nervura mediana com células esclerenquimáticas (Es) na face adaxial e endoderme (En) envolvendo o feixe vascular $($ barra $=100 \mu \mathrm{m})$. 

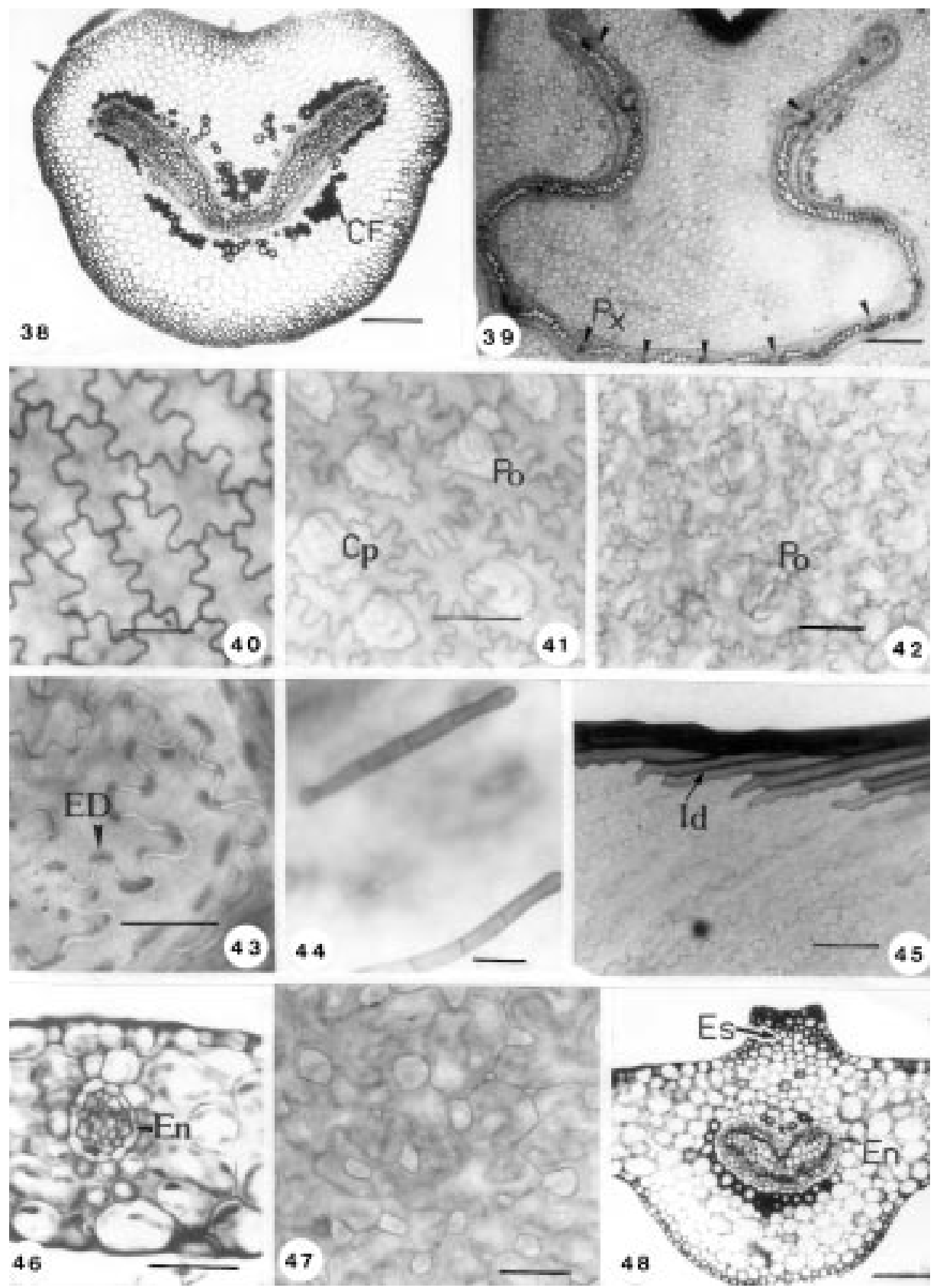

Figuras 38-48. Estrutura foliar de Pteris. 38-39. Cortes transversais do pecíolo. 38. Meristelo em forma de "U”; compostos fenólicos (CF) próximo ao meristelo, em $P$. leptophylla: $($ barra $=25 \mu \mathrm{m})$. 39. Meristelo em forma de ômega $(\Omega)$ invertido, com inúmeros pólos de protoxilema $(\mathrm{Px})$, em P. propinqua $($ barra $=50 \mu \mathrm{m}$ ). 40-45. Lâmina foliar diafanizada. 40 e 41 . P. denticulata var. denticulata. 40. Epiderme adaxial com células lobadas (barra $=10 \mu \mathrm{m}$ ). 41. Epiderme abaxial com células profundamente lobadas; estômatos polocíticos $(\mathrm{Po})$ e copolocíticos $(\mathrm{Cp})($ barra $=10 \mu \mathrm{m})$. 42. Epiderme abaxial, com células de paredes anticlinais recortadas e estômatos polocíticos $(\mathrm{Po})$, em $P$. propinqua (barra $=5 \mu \mathrm{m})$. 43. Paredes anticlinais das células epidérmicas com espessamento diferenciado (ED), em $P$. denticulata var. denticulata $($ barra $=10 \mu \mathrm{m})$. 44. Pêlos tectores unisseriados e pluricelulares, em $P$. propinqua $($ barra $=10 \mu \mathrm{m})$. 45. Idioblastos $(\mathrm{Id})$ reforçando as margens do limbo, em $P$. leptophylla $($ barra $=10 \mu \mathrm{m}) .46-48$. Cortes transversais e paradérmico da lâmina foliar de $P$. denticulata var. denticulata. 46. Mesofilo homogêneo, feixe vascular envolvido pela endoderme (En) (barra $=50 \mu \mathrm{m})$. 47. Corte paradérmico mostrando parênquima com células lobadas (barra $=5 \mu \mathrm{m}$ ). 48 . Nervura mediana com esclerênquima subepidérmico (Es) e feixe anficrival envolvido pela endoderme $(\mathrm{En})(\mathrm{barra}=100 \mu \mathrm{m})$. 
com traqueídes aneladas e espiraladas no protoxilema e escalariformes no metaxilema.

A lâmina foliar de $P$. calomelanos var. calomelanos apresenta epiderme uniestratificada. Em vista frontal, as células da epiderme adaxial são estreitas, longas, paralelas às nervuras, e têm paredes anticlinais levemente onduladas (figura 34). $\mathrm{Na}$ epiderme abaxial ocorrem: células alongadas de paredes anticlinais sinuosas; estômatos diacíticos e anomocíticos (figura 35); pêlos glandulares, com a célula apical volumosa e globosa (figura 36) e idioblastos esclerenquimáticos, apenas na região das nervuras.

O mesofilo tende a dorsiventral sem contudo haver diferenciação de um parênquima paliçádico típico. O parênquima clorofiliano em contato com a epiderme adaxial é mais compacto e possui células ligeiramente alongadas no plano anticlinal (figura 36).

O sistema vascular está constituído por um feixe anficrival, de maior porte, situado na região da nervura mediana (figura 37) e por feixes colaterais, de menor porte, situados próximos a epiderme abaxial, ambos envolvidos por uma endoderme cujas células apresentam conteúdo fenólico.

Gênero Pteris L. (figuras 38-48; tabela 1).

O pecíolo das espécies de Pteris apresenta epiderme uniestratificada, com células de paredes celulósicas. O córtex é constituído por esclerênquima (fibras) e parênquima; próximo à endoderme, foram observadas manchas escuras, resultantes do acúmulo de compostos fenólicos, nas quais não se individualiza o limite das células e nem a parede celular (figura 38). A endoderme envolve o único meristelo e suas células podem, às vezes, evidenciar conteúdo escuro, como em $P$. propinqua.

O meristelo (figuras 38,39 ) apresenta periciclo formado de uma ou mais camadas de células, às vezes volumosas como em $P$. propinqua, e várias camadas de floema em torno do xilema. Em $P$. denticulata var. denticulata e P. leptophylla, o xilema tem forma de "U" (figura 38), com as margens em ganchos recurvados, do tipo "Loxsoma", com quatro pólos de protoxilema. Em P. propinqua tem a forma de ômega $(\Omega)$ invertido, do tipo "Pteris podophylla", com inúmeros pólos de protoxilema (figura 39). Traqueídes espiraladas e aneladas ocorrem no protoxilema e escalariformes no metaxilema.

A epiderme da lâmina foliar é uniestratificada, formada por células profundamente lobadas (figuras
40-43), em vista frontal, tanto na face adaxial e abaxial apresenta espessamento diferenciado das paredes (figura 43). Em Pteris propinqua as paredes anticlinais são mais recortadas (figura 42) do que as paredes anticlinais das outras duas espécies. Os estômatos estão presentes somente na face abaxial das pínulas e são dos tipos polocítico e copolocítico (figuras 41, 42). Em ambas as faces da lâmina foliar, ocorrem pêlos tectores unisseriados, pluricelulares, com a célula apical clavada (figura 44). Os pêlos podem ser esparsos, como em $P$. denticulata var. denticulata e P. leptophylla, ou densamente dispostos, como em $P$. propinqua. Nas margens da lâmina foliar, de $P$. denticulata var. denticulata e $P$. leptophylla, a epiderme é constituída por idioblastos esclerenquimáticos (figura 45).

O mesofilo é homogêneo com células lobadas (figura 47), tendendo a isodiamétricas (figura 46), de paredes delgadas. O sistema vascular da lâmina foliar está representado por um feixe anficrival de maior porte, na região da nervura mediana (figura 48), e por feixes colaterais de menor porte, situados na região mediana do mesofilo, ambos circundados pelo periciclo e pela endoderme (figuras 46,48 ). Na região da nervura mediana ocorre esclerênquima subepidérmico (figura 48).

\section{Discussão e Conclusões}

A presença de compostos fenólicos é uma característica marcante nas Pteridophyta. Esses compostos conferem uma coloração marrom, principalmente aos tecidos de sustentação e ao parênquima próximo aos feixes (Ogura 1972). No pecíolo das espécies de Adiantum, Hemionitis e Pityrogramma, os compostos fenólicos ocorreram, principalmente, na epiderme e no tecido subepidérmico e, também, nas células próximas à endoderme ou até mesmo como conteúdo das células da endoderme e das células parenquimáticas do floema. Na lâmina foliar, os compostos fenólicos apareceram somente como conteúdo das células da endoderme. Segundo Taiz \& Zeiger (1998) além do suporte mecânico, os compostos fenólicos podem proporcionar à planta proteção contra a herbivoria $\mathrm{e}$ a patogenicidade, além de possuir atividade alelopática.

Outra característica marcante observada em várias das espécies de Pteridaceae estudadas foi a presença de idioblastos esclerenquimáticos na 
epiderme. Provavelmente, estas células estejam relacionadas à sustentação da folha, como comentado por Nayar (1962). Esse autor afirma, a partir do estudo de 24 espécies de Adiantum, que essas células estão, em geral, restritas à região das nervuras e presentes somente na face adaxial das pínulas. Entretanto, nas espécies de Adiantum do PERD, os idioblastos foram encontrados, na maioria das vezes, em ambas as faces da folha e distribuídos por toda a lâmina foliar; apenas em Adiantum curvatum, A. papillosum e A. subcordatum os idioblastos ocorreram somente nas nervuras. É importante ressaltar que, para utilização dos idioblastos na taxonomia de Pteridaceae, a observação de material diafanizado, sob microscopia de luz, revelou-se essencial pois permitiu verificar, com exatidão, a presença deste tipo de célula e sua distribuição na lâmina foliar.

O uso dos idioblastos na taxonomia foi citado por Moran \& Yatskievych (1995), para separação das espécies de Adiantum, e os dados obtidos no estudo das espécies do PERD reforçam a importância desse caráter. Idioblastos mais curtos que os da lâmina, e perpendiculares às nervuras, foram observados no indúsio da maioria das espécies de Adiantum estudadas. Na bibliografia disponível não se encontrou nenhuma citação relacionada com essa localização.

O estudo da epiderme tem fornecido caracteres relevantes para a taxonomia das plantas vasculares destacando-se entre eles os tricomas e os estômatos (Metcalfe \& Chalk 1979, Fahn 1990). Os apêndices epidérmicos têm sido utilizados na separação de famílias, gêneros e espécies de Pteridophyta (Tryon \& Tryon 1982, Tryon \& Stolze 1989). No presente estudo, pêlos e escamas foram importantes para a identificação de gêneros de Pteridaceae e espécies do gênero Adiantum. Pêlos glandulares ocorreram apenas em Hemionitis tomentosa e Pityrogramma calomelanos var. calomelanos. Nesta última espécie, os pêlos observados na superfície abaxial da lâmina foliar secretam, provavelmente, o indumento farináceo característico do gênero. Pêlos tectores não foram observados em Pityrogramma e no gênero Adiantum ocorrem, apenas, na lâmina foliar e pecíolo de A. terminatum e no pecíolo de A. papillosum. As escamas foram mais características do gênero Adiantum.

Nas espécies de Pteridaceae aqui tratadas, estômatos do tipo anomocítico foram os mais freqüentes, aparecendo na maioria das espécies de
Adiantum, em Hemionitis tomentosa e Pityrogramma calomelanos var. calomelanos. Em Adiantum papillosum, A. subcordatum e em Pityrogramma calomelanos var. calomelanos, além de estômatos anomocíticos, ocorreram estômatos diacíticos. Nas espécies de Pteris, o tipo de estômato mais comum foi o polocítico associado ao tipo copolocítico. Van Cotthem (1973) cita para Pteridaceae estômatos polocíticos, anomocíticos e paracíticos. Os estômatos anomocíticos são considerados estruturalmente mais simples e de ocorrência ampla, podendo estar associados a outros tipos (Sen \& De 1992). Como já enfatizado por Thurston (1969), Van Cotthem (1973), Metcalfe \& Chalk (1979) e Fahn (1990), os estômatos apresentam um grande valor taxonômico.

Segundo Ogura (1972) e Tryon \& Tryon (1982), o tipo e a disposição dos feixes vasculares de Pteridophyta são importantes para a determinação de famílias, gêneros e espécies. Os dados obtidos neste estudo estão de acordo com Tryon \& Kramer (1990), que citam para a família Pteridaceae 1-4 feixes vasculares próximos à base do pecíolo. De acordo com Nayar (1962), dependendo do tamanho das pinas, os feixes do pecíolo podem unir-se próximo ao rizoma ou próximo à lâmina foliar. Daí a importância de, nos estudos de vascularização, secionar os pecíolos em diferentes níveis, para determinar o número e o tipo de feixe vascular presente. Nas espécies estudadas, a tendência geral foi a fusão dos feixes vasculares na região distal do pecíolo.

No PERD, a maioria das espécies de Pteridaceae foi coletada em locais sombreados e apenas duas a pleno sol (Adiantum serratodentatum e Pityrogramma calomelanos var. calomelanos). Observa-se na estrutura foliar das espécies estudadas, características que refletem uma adaptação aos ambientes com diferenças na intensidade luminosa. Segundo Metcalf \& Chalk (1979) e Fahn (1990), as folhas expostas ao sol, quando comparadas com as de ambientes sombreados, caracterizam-se por apresentar, em geral, menor área foliar, mesofilo mais espesso e compacto, parênquima paliçádico e lacunoso diferenciados, tricomas mais numerosos, dentre outras características.

Entre as espécies encontradas em locais sombreados, Adiantum curvatum foi a única que apresentou o mesofilo extremamente estreito, constituído por uma ou duas camadas de células. Nas espécies coletadas a pleno sol, verificou-se uma tendência para uma estrutura dorsiventral nas folhas 
de Pityrogramma calomelanos var. calomelanos, nas quais o parênquima clorofiliano voltado para a face adaxial possui células um pouco mais alongadas anticlinalmente. Essa tendência, entretanto, não foi observada em Adiantum serratodentatum, cujo mesofilo apresenta-se indiferenciado em consequiência, provavelmente, da disposição de suas folhas que são mais verticais, em relação aos raios solares, do que as de P. calomelanos var. calomelanos. Desta forma, as folhas de $A$. serratodentatum recebem intensidade luminosa semelhante nas duas faces da lâmina o que, em geral, induz a diferenciação de um mesofilo homogêneo constituído por parênquima clorofiliano propriamente dito.

Na lâmina foliar das espécies que ocorrem em locais sombreados, as células da epiderme adaxial são alongadas, clorofiladas e apresentam projeções unguladas nas paredes periclinais internas. Essas células podem ser interpretadas funcionalmente, em plantas de ambientes com pouca luz, como um parênquima paliçádico pois proporcionam melhor captação da energia luminosa. Além disso, tais células facilitam o transporte de metabólitos pois nas folhas de Pteridophyta o padrão de venação, com feixes vasculares de pequeno porte e bastante separados, dificulta a translocação de materiais entre as nervuras (Wylie 1948).

As espécies de Adiantum, que ocorrem no PERD, apresentaram as células epidérmicas das duas faces da lâmina foliar com paredes anticlinais sinuosas, e em geral, a face abaxial, aquela que recebe menos luz, apresenta as paredes mais sinuosas. Hemionitis tomentosa não apresentou diferença na sinuosidade das paredes anticlinais das células epidérmicas das duas faces da folha. Em Pityrogramma calomelanos var. calomelanos, espécie coletada a pleno sol, as paredes anticlinais da face adaxial são quase retas, enquanto as da face abaxial são sinuosas. Em Pteris propinqua, encontrada no interior de mata e em local bastante sombreado, as paredes anticlinais das células epidérmicas são muito mais sinuosas do que as das outras duas espécies do gênero ( $P$. denticulata var. denticulata e P. leptophylla) que foram encontradas em locais menos sombreados.

As ondulações na parede das células epidérmicas são mais pronunciadas nas folhas de sombra, enquanto nas folhas de sol e de ambientes xéricos, as células epidérmicas têm, em geral, paredes anticlinais retas (Sharma \& Dunn 1968, Wilkinson 1979). Watson (1942) verificou que em plantas de Hedera helix, desenvolvidas em ambientes sombreados, as paredes das células epidérmicas permanecem, por longo período de tempo, mais delicadas e plásticas, o que favorece o desenvolvimento das sinuosidades. Nas folhas de sol, as paredes das células epidérmicas expandem-se menos e, juntamente com a cutícula, se espessam e endurecem rapidamente resultando em paredes mais retilíneas.

Um espessamento desigual das paredes anticlinais das células epidérmicas, não observado nos outros gêneros estudados, foi visualizado nas espécies de Pteris. Entretanto, é prematuro afirmar que se trata de uma característica do gênero, pois, até o momento, apenas três espécies de Pteris foram coletadas no Parque.

Semelhante às plantas vasculares com sementes, as características anatômicas em Pteridophyta também têm-se mostrado úteis para a taxonomia. A partir dos estudos morfo-anatômicos das espécies de Pteridaceae, é possível inferir que as espécies de Adiantum do Parque estão separadas em dois grupos, pois Adiantum papillosum e A. subcordatum têm em comum, e diferente das outras dez espécies do gênero o tipo de feixe vascular do pecíolo, o formato das células das epidermes abaxial e adaxial, os tipos de estômatos e de tricomas. Acrescidas a estas, têm-se ainda as características de morfologia externa como forma das pínulas e divisão da lâmina foliar. O caráterdiagnóstico que distingue Adiantum papillosum de A. subcordatum é a presença de pêlos simples, unicelulares e de ápice rombudo no pecíolo, peciólulo e raque de A. papillosum. Assim, serão necessários estudos mais detalhados da micromorfologia foliar, em microscopia eletrônica de varredura, e da ontogenia da folha, para auxiliar na distinção ou até mesmo união desses táxons.

O estudo destas 17 espécies de Pteridaceae evidenciou caracteres anatômicos promissores na identificação das espécies do PERD, podendo ser destacados, entre outros: presença de tricomas (pêlos ou escamas) no pecíolo e na lâmina foliar; tipos de estômatos; presença e distribuição dos idioblastos esclerenquimáticos na epiderme e tipos e disposição dos feixes vasculares do pecíolo (meristelo).

\section{Referências bibliográficas}

BERLYN, G.P. \& MIKSCHE, J.P. 1976. Botanical microtechnique and cytochemistry. The Iowa State Press, Ames. 
BOWER, F.O. 1923. The ferns (filicales): treated comparatively with a view to their natural classification v.1. Today, Tomorrow's Book Agency, New Delhi.

COPELAND, E.B. 1947. Genera filicum. Chronica Botanica. Waltham, Massachussets.

DICKISON, W.C. 1975. The bases of angiosperm phylogeny: vegetative anatomy. Annals of the Missouri Botanical Garden 62:590-620.

FAHN, A. 1990. Plant anatomy. 4ed. Pergamon Press, New York.

FRYNS-CLAESSENS, E. \& VAN COTTHEM, W. 1973. A new classification of the ontogenetic types of stomata. Botanical Review 39:71-131.

GRAÇANO, D., PRADO, J. \& AZEVEDO, A.A. 1998. Levantamento preliminar de Pteridophyta do Parque Estadual do Rio Doce (MG). Acta Botanica Brasilica 12:165-181.

GUANTAY, M.E. \& TERÁN, M.H. 1995. Estudio morfoanatómico de las especies del género Elaphoglossum Schott de Tucumán. Lilloa 38:73-84.

IEF (INSTITUTO ESTADUAL DE FLORESTAS). 1994. Pesquisas prioritárias para o Parque Estadual do Rio Doce, Brasil. IEF, Belo Horizonte.

JOHANSEN, D.A. 1940. Plant microtechnique. McGraw Hill, New York.

KROPP, U. 1972. Leitbündel. Mikrokosmos 61:342-345.

LANGERON, M. 1949. Précis de microscopie. Masson et Cie. Editeurs, Paris.

METCALFE, C.R. \& CHALK, L. 1979. Anatomy of the dicotyledons: systematic anatomy of the leaf and stem v.1. 2ed. Oxford University Press, New York.

METCALFE, C.R. \& CHALK, L. 1983. Anatomy of the dicotyledons: wood structure and conclusion of the general introduction. 2ed. Oxford University Press, New York, v.2.

MORAN, R.C. \& YATSKIEVYCH, G. 1995. Pteridaceae: Adiantaceae, Parkeriaceae, descrição de la família y chave genérica. In Flora Mesoamericana. I. PsilotaceaeSalviniaceae. (G. Davidse, M.S. Sousa \& S. Knapp, eds.). Universidad Nacional Autónona de México, México, D.F., p.104-105.

NAYAR, B.K. 1962. Studies in Pteridaceae V. Contributions to the morphology of some species of the maidenhair ferns. Botanical Journal of Linnean Society 185:185199.

OGURA, Y. 1972. Comparative anatomy of vegetative organs of the pteridophytes. 2ed. Gebrüder Bornt raeger, Berlin.

PICHI-SERMOLLI, R.E.G. 1958. The higher taxa of Pteridophyta and their classification. In Systematics of today. (O. Hedberg, ed.). Uppsala Universitets Årsskrift 6:70-90.

PRADO, J. 1989. Os representantes da família Pteridaceae, subfamília Cheilanthoideae (Div. Pteridophyta) ocorrentes nos campos rupestres da Cadeia do Espinhaço no Estado de Minas Gerais, Brasil. Dissertação de mestrado, Universidade de São Paulo, São Paulo.
PRADO, J. 1993. Revisão taxonômica de Pteris L. (Pteridaceae) no Brasil. Tese de doutorado, Universidade de São Paulo, São Paulo.

PURVIS, M.J., COLliER, D.C. \& WALlS, D. 1964. Laboratory techniques in botany. Butterworths, London.

ROESER, K.R. 1972. Die nadel der schwarzkiefer. Massenprodukt und kunstwerk der natur. Mikrokosmos 61:33-36.

SEN, U. \& DE, B. 1992. Structure and ontogeny of stomata in ferns. Blumea 37:239-261.

SHARMA, G.K. \& DUNN, D.B. 1968. Effect of environment on the cuticular features in Kalanchoë fedschenkoi. Bulletin of the Torrey Botanical Club 95:464-473

SOCT (SISTEMA OPERACIONAL DE CIÊNCIA E TECNOLOGIA). 1981. Programa de pesquisas ecológicas no Parque Florestal Estadual do Rio Doce. Relatório final v.2. CETEC, Belo Horizonte.

SOLEREDER, H. 1908. Systematic anatomy of the dicotyledons. Claredon Press, Oxford, v.1.

STACE, C.A. 1989. Plant taxonomy and biosystematics. 2ed. Edward Arnold, London.

TAIZ, L. \& ZEIGER, E. 1998. Plant physiology. 2ed. Sinauer Associates, Inc. Publishers, Massachusetts.

THURSTON, E.L. 1969. Taxonomic significance of stomatal patterns in the ferns. American Fern Journal 59:68-79.

TRYON, R.M. \& KRAMER, K.U. 1990. Pteridaceae. In The families and genera of vascular plants. (K. Kubitzki, ed.). Springer Verlag, New York, p.230-256.

TRYON, R.M. \& STOLZE, R.G. 1989. Pteridophyta of Peru. Part II. 13. Pteridaceae-15. Dennstaedtiaceae. Fieldiana Botany, n. s., 22:1-128.

TRYON, R.M. \& TRYON, A.F. 1982. Ferns and allied plants, with special reference to Tropical America. Springer Verlag, New York.

VAN COTTHEM, W.R.J. 1973. Stomatal types and systematics. In The phylogeny and classification of the ferns (J.A. Crabbe \& B.A. Thomas, eds.). Academic Press, London, Botanical Journal of Linnean Society 67(Suppl. 1):59-71.

VELOSO, H.P., RANGEL FILHO, A.L.R. \& LIMA, J.C.A. 1991. Classificação da vegetação brasileira, adaptada a um sistema universal. IBGE, Rio de Janeiro.

WATSON, R.W. 1942. The effect of cuticular hardening on the form of epidermal cells. New Phytologist 41:223229.

WHITE, R.A. 1974. Comparation anatomical studies of the ferns. Annals of the Missouri Botanical Garden 61:379387.

WILKINSON, H.P. 1979. The plant surface (mainly leaf). In Anatomy of the Dicotyledons v.1. 2ed. (C.R. Metcalf \& I. Chalk, eds). Oxford University Press, New York, p.97165.

WYLIE, R.B. 1948. The dominant role of the epidermis in leaves of Adiantum. American Journal of Botany 35:465473. 
